\title{
Non-standard Sources for Arms Production and Arms Trade Data*
}

Filiz AKBAŞ-YEŞiLYURT ${ }^{1}$

M. Ensar YEŞILYURT2*

https://orcid.org/0000-0003-1629-4747

https://orcid.org/0000-0001-5610-3146

\begin{abstract}
Even though there are a range of useful sources on defence economics data, only some of them are used widely. The main sources of export, import and output data sets are Stockholm International Peace Research Institute (SIPRI), World Military Expenditures and Arms Transfers-US Department of State (WMEAT), European Statistical Office (EUROSTAT) and United Nations Industrial Development Organization (UNIDO) while SIPRI and WMEAT are for military expenditures. This paper discusses the main features and similarities of data sets from the various sources. Like other industrial/ sector data sets, the main problem for arms data sets is revisions of industrial classifications, which prevent the creation of long time series.
\end{abstract}

Keywords: Arms data set issues

JEL Codes: L6, C8

\section{Introduction}

This paper discusses the data available on the output of the arms industry and the arms trade in the context of the wider defence data. Making international comparisons of output, expenditure or trade over time is inherently difficult because of the issues in allowing for changes in prices and exchange rates. This is even more difficult for military variables like arms output or trade. There are no agreed definitions of what can be classified as arms and there is much dual-use equipment, trucks and helicopters that have both military and civilian uses. In addition, many countries release limited amounts of data about military expenditures or outputs. Many studies point out these issues and provide some suggestions. For example, Smith and Dunne (2018) examined the relation between arms sales and military expenditure, concentration and size of firms. Silva (2018) stresses the disaggregation of data sets and better presentation. Wulf (2018) suggests comparisons between the SIPRI top 100 arms producers data with the civilian sector. Hartley (2018) discusses the features, collection and distribution of data sets. Perlo-Freeman discusses the link between the arms trade and corruption. Fleurant and Yian (2018) specifically focus on SIPRI's arms producing data sets and points out some drawbacks.

Taking these difficulties as given, we reviewed the data on armaments, starting with the familiar sources, SIPRI and WMEAT, and moving on to less familiar ones; UNIDO, EUROSTAT and COMTRADE. Although they are widely used in other parts of economics, these other data sources have not been widely used in defence economics. The exceptions are Kinsella (2000) and Yesilyurt et al. (2014).

There are a number of possible reasons for their neglect. Rather than referring to the production or trade of arms as a whole, they refer to subsets, e.g. manufacturing of weapons and ammunition. These subsets can be well-defined, but there are many important categories where military and civilian products cannot be distinguished such as aircrafts. In addition, 
even a category like weapons and ammunition would include some non-military uses such as for policing and hunting, among others.

Although these sources use well-defined hierarchical classification systems, their definitions do not match each other. The Harmonized Commodity Description and Coding System of the World Customs Organisation; the UN Standard International Trade Classification, SITC, or the International Standard Industrial Classification, ISIC do not correspond. This makes matching production and international trade figures difficult.

Because of changes in the structure of the economy and the types of products available, these classification systems are regularly revised. This means that it is difficult to get long runs of consistent series. For instance, the United Nations Industrial Development Organisation provides data for ISIC (international standard industrial classification). The definitions have been revised over time. Revision 1 was published in 1958, Revision 2 published in 1968, Revision 3 published in 1989, Revision 3.1 published in 2002 and Revision 4 published in 2008. While each revision defined industries in more detail, the process of revision precludes the creation of long time series for individual sectors because of changes in the definition of sectors.

Because particular products may not be produced or traded (or the production or trade is not reported) there tends to be many zeros in the data. Zeros are a problem in many studies of disaggregated trade.

\section{Main Data Sources}

\section{SIPRI}

The Stockholm International Peace Research Institute (SIPRI) is one of the best known defence data sources. It has four main databases available for electronic downloading on its website. ${ }^{1}$ We will not discuss the Multilateral Peace Operations Database and discuss the other three briefly below.

The Military Expenditure Database contains time series on the military expenditures of countries from 1949 and is updated annually while being based on open sources only. It is presented in local currency, constant US dollars, current US dollars, share of GDP per capita and share of government expenditure.
The Arms Industry Database presents data on the top 100 arms producers, excluding China for which there is little data. The Database was initiated in 1989, but the main data goes back to 2002.

The Arms Transfers Database contains information on all transfers of major conventional weapons since 1950 and is updated annually. The files can be generated from the internet page as bilateral export and imports either as the product base or in total. The data is aggregated using Trend Indicator Values. There is also some data on the financial value of the global arms trade.

\section{WMEAT}

The U.S. Department of State-World Military Expenditures and Arms Transfers (WMEAT) contains a range of data for download from its website. ${ }^{2}$ Here we focus on two sets of data. Prior to 1999 it was published by the Arms Control and Disarmament Agency and is often referred to as ACDA data.

Military expenditure, armed forces, GDP, population, labor force, and their ratios. WMEAT 2017 presents data for 2005-2015, but spreadsheets for previous years and pdf versions for the more distant past are available. The numbers in the armed forces data are not easily accessible elsewhere and the military expenditures as well as being presented in similar ways to SIPRI, use a number of different conversion rates including an estimate of a defence based PPP.

Arms Trade: Spreadsheets provide arms imports and exports aggregated in various ways, again over 2005-2015 in the latest version. Older data is available in spreadsheets or pdf files. Whereas SIPRI looks at major weapons systems values using Trend Indicator Values, WMEAT has a wider definition of weapons and values at transaction prices.

\section{UNIDO}

Revision 3 classification ${ }^{3}$ or ISIC revision $4^{4}$ classification. Leaving classification issues in Online Appendix 1 to save space, we are discussing other issues about this source

Data sets in ISIC Revision 3 usually starts from 1990 while ISIC Revision 4 starts usually runs from 2005 to 2015.

\footnotetext{
1https://www.sipri.org/databases

${ }^{2}$ https://www.state.gov/t/avc/rls/rpt/wmeat/

${ }^{3}$ https://stat.unido.org/content/dataset_description/idsb-2018\%252c-isic-revision-3

${ }^{4}$ https://stat.unido.org/content/dataset_description/idsb-2018\%252c-isic-revision-4
} 
Arms Production: This is one of the broadest data sets for arms production. Data sets are given in ISIC Revision 3 and Revision 4 in either two digits or four digits. ISIC Revision 3 has a class directly for the arms industry that is 2927 Manufacture of Weapons and Ammunition (Online Appendix 2).

This class includes the manufacture of: tanks and other fighting vehicles; heavy weapons (artillery, mobile guns, rocket launchers, torpedo tubes, heavy, machine guns); small arms (revolvers, shotguns, light machine guns); air or gas guns and pistols; war ammunition; military ballistic and guided missiles, hunting, sporting or protective firearms and ammunition; explosive devices such as bombs, mines and torpedoes. This class excludes the manufacture of percussion caps, detonators or signaling flares, see 2429; cutlasses, swords, bayonets etc., see 2893; armored vehicles for the transport of banknotes or valuables, see 3410 .

ISIC Revision 4 categorizes the defense industry in three classes: Weapons and Ammunition ISIC2520; Military Fighting Vehicles ISIC3040, which are removed from weapons and ammunition and become a separate class; and Defence Activities ISIC8422, which covers the operations of the military. Each class covers more detailed definitions for the products (Online Appendix 3).

Arms Trade: UNIDO presents international trades figures. Data sets either use ISIC Revision 3 or Revision 4 and have figures for total imports, total exports, apparent consumption and imports from developing and emerging industrial economies. Imports from industrialized economies. Exports to developing and emerging industrial economies. Exports to industrialized economies.

\section{EUROSTAT}

ISIC is an umbrella classification and countries may aggregate or disaggregate within the ISIC categories when adapting ISIC to national circumstances. The system of statistical classification of economic activities for the EU, NACE (Nomenclature statistique des activités économiques dans la Communauté européenne) is an example of this. The Statistical Office of the European Communities, EUROSTAT, publishes arms export and arms imports and arms productions in NACE 1 and 2 classifications. Data sets can be generated on the EUROSTAT page ${ }^{5}$ from 2009 to the most recent year.

Arms Production: Data sets can be organised to NACE Revision 1 or 2 from 1990 to most recent years. NACE Revision 1 arms products are covered by 2960 Manufacture of weapons and ammunition and include some the items (Online Appendix 4). NACE Revision 2 arms products are covered by 2540 Manufacture of Weapons and Ammunition, 2571 Manufacture of cutlery and 2670 Manufacture of optical instruments and photographic equipment. They include several items (Online Appendix 5). Data sets include figures for production quantity and production value.

Arms Trade: The features are the same as Arms Production of EUROSTAT. Data sets include figures for Export quantity, Export value, Import quantity, Import value. There are some issues about these data sets. Even though item "Motorized tanks and other armored fighting vehicles and parts thereof" of NACE 1 is not seen in NACE 2 clearly, according to correspondence tables ${ }^{6}$ it is included in 2540 . Besides the previous one, some other items in 2960 of NACE 1 are covered by 30.30 Manufacture of air and spacecraft; 30.40 Manufacture of military fightings; and 33.11 Repair of fabricated metal products of NACE2. However, in EUROSTAT data sets there is no information and figures about these codes in NACE2 data sets. On the other hand, according to other correspondence tables from NACE 2 to NACE 1 2540 and 3040 of NACE 2 are covered by 2960 of NACE $1{ }^{7}$. According to the latter tables, item Manufacture of intercontinental ballistic missiles (ICBM) of NACE 1 is covered by 3030 Manufacture of air and spacecraft and related machinery of NACE 2 . However, there are no figures in the data sets.

\section{UN COMTRADE}

The UN International Trade Statistics Database, COMTRADE ${ }^{8}$, offers comprehensive data sets for imports and exports of particular categories of arms. As with

\footnotetext{
${ }^{5}$ (http://appsso.eurostat.ec.europa.eu/nui/show.do?query=BOOKMARK_DS-066341_QID_-47D72158_UID_-3F171EB0\&layout=INDICA TORS,C,X,0;DECL,L,Y,0;PRCCODE,B,Z,0;PERIOD,L,Z,1;\&zSelection=DS-066341 PERIOD,200952;DS-066341PRCCODE,07101000;\&rankName1=PRCCODE_1_0_-1_2\&rankName2=DECL_1_0_0_1\&rankName3=INDICATORS_1_0_0_0\&rankName4=PERIOD_1_0_-1_2\&sortR=ASC_-1_

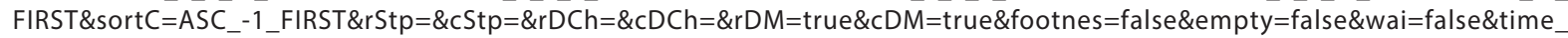
mode=ROLLING\&lang=en)

${ }^{6} \mathrm{http}: / /$ ec.europa.eu/eurostat/documents/1965800/1978760/CORRESPONDENCETABLENACEREV.1.1-NACEREV.2.pdf/e8200936-c2f04202-8bda-99fbbfc422b4 access on 20 August 2018)

${ }^{7} \mathrm{http} / / /$ ec.europa.eu/eurostat/documents/1965800/1978760/CORRESPONDENCETABLENACEREV.2NACE-REV.1.1.pdf/df9cd8a8-0b4a4197-bad7-727a0b9fd59b accessed on 20 August 2018).

${ }^{8}$ https://comtrade.un.org/data/
} 
the SIPRI-TIV data sets, one can get bilateral exports and imports commodity by commodity for countries. Alternative classification systems are available to query. When SITC Revision 3 is used to query, data sets for arms exports and imports for different codes (commodity or commodity group) can be generated. Another source is CEPII.fr, which is generated data mostly relying on COMTRADE. The data sets usually cover: Reporter, Partner, Commodity, Quantity type, Quantity unit, Netweight, Trade value.

The data sets include a number of codes related to the arms industry: 8911 Armored fighting vehicles and arms of war, 8912 Bombs, grenades, torpedoes, mines, missiles and similar munitions of war and parts thereof, cartridges and other ammunition and projectiles, and parts thereof, including shot and cartridge wads, 8913 Non-military arms and 87191 Telescopic sights for fitting to arms, periscopes, telescopes designed to form parts of machines appliances, instruments or apparatus of section 7 division 87 , group 881 or 884 or subgroup 899.6,

\section{Other Sources}

Other sources which provide useful information for specific issues are

Central Intelligence Agency (CIA) https://www.cia. gov/library/publications/the-world-factbook/rankorder/2034rank.html

North Atlantic Treaty Organization (NATO) https://www.nato.int/nato_static_fl2014/assets/pdf/ pdf_2017_06/20170629_170629-pr2017-111-en.pdf

United Nations (UN) http://data.un.org/Data.aspx?$\mathrm{d}=$ WDI\& $\mathrm{f}=$ Indicator_Code\%3AMS.MIL.XPND.GD.ZS (based on World Bank and World Bank's data sets are based on SIPRI).

\section{Main Futures of the Datasets}

In this section, some descriptive features of data sets, which were focused in this study.

In Table 1, there are the names and their periof of variables used.

In the first column of the table, there are variable names and their abbreviations used in the study. In the second column, there are original periods of data sets, some of which have long time series. For example, the original periods of data sets of export and import of SIPRI start from 1950. On the other hand, these and other longer data sets have a lot of missing data or zeros for which is the reason is not clear.

Table 1: Variable list

\begin{tabular}{|c|c|c|}
\hline Variable & Period & Source \\
\hline Export (COMTRADE) & $1988-2017$ & COMTRADE \\
\hline Export (ISIC Revision 3) & $1981-2015$ & UNIDO \\
\hline Export (ISIC Revision 4) & $2005-2015$ & UNIDO \\
\hline Export (NACE Revision 1) & $1995-2012$ & EUROSTAT \\
\hline Export (NACE Revision 2) & $1995-2015$ & EUROSTAT \\
\hline Export (SIPRI) & $1950-2017$ & SIPRI \\
\hline Export (WMEAT) & 1989-2017 & USA Dep. of STATE \\
\hline $\begin{array}{l}\text { GDP-Constant } \$ \text { (Converted at } \\
\text { real MER, base 2015) }\end{array}$ & $1964-2017$ & USA Dep. of STATE \\
\hline $\begin{array}{l}\text { GDP-Constant \$ per capita } \\
\text { (Converted at real MER, base 2015) }\end{array}$ & 1987-2017 & USA Dep. of STATE \\
\hline $\begin{array}{l}\text { GDP-Constant \$ per capita, } \\
\text { base } 2010\end{array}$ & $1960-2017$ & WORLD BANK \\
\hline GDP-Constant \$, base 2010 & $1960-2017$ & WORLD BANK \\
\hline Import (COMTRADE) & 1988-2017 & COMTRADE \\
\hline Import (ISIC Revision 3) & $1981-2015$ & UNIDO \\
\hline Import (ISIC Revision 4) & $2005-2015$ & UNIDO \\
\hline Import (NACE Revision 1) & $1995-2012$ & EUROSTAT \\
\hline Import (NACE Revision 2) & $1995-2015$ & EUROSTAT \\
\hline Import (SIPRI) & $1950-2017$ & SIPRI \\
\hline Import (WMEAT) & $1989-2017$ & USA Dep. of STATE \\
\hline Military Expenditure/GDP & $1949-2016$ & SIPRI \\
\hline $\begin{array}{l}\text { Military Expenditure/GDP } \\
\text { (National currency) }\end{array}$ & $1964-2017$ & WMEAT \\
\hline $\begin{array}{l}\text { Military Expenditure/ } \\
\text { Government Expenditure }\end{array}$ & $1988-2016$ & SIPRI \\
\hline Military Expenditure-Constant $\$$ & $1973-2015$ & SIPRI \\
\hline $\begin{array}{l}\text { Military Expenditure-Constant } \\
\$(\text { Converted at current-year- } \\
\text { average MER, base } 2015)\end{array}$ & $1989-2017$ & USA Dep. of STATE \\
\hline $\begin{array}{l}\text { Military Expenditure-Constant } \\
\$(\text { Converted at PPP-for-GDP } \\
\text { rate, base 2015) }\end{array}$ & $1989-2017$ & USA Dep. of STATE \\
\hline $\begin{array}{l}\text { Military Expenditure-Constant } \\
\text { per capita }\end{array}$ & $1988-2016$ & SIPRI \\
\hline $\begin{array}{l}\text { Military Expenditure-Constant per } \\
\text { capita (Converted at current-year- } \\
\text { average MER, base } 2005 \text { dollars) }\end{array}$ & $1987-2017$ & USA Dep. of STATE \\
\hline Output (ISIC Revision 3) & $1981-2015$ & UNIDO \\
\hline Output (ISIC Revision 4) & $2005-2015$ & UNIDO \\
\hline Output (NACE Revision 1) & $1995-2012$ & EUROSTAT \\
\hline Output (NACE Revision 2) & $1995-2015$ & EUROSTAT \\
\hline Population & $1960-2017$ & WORLD BANK \\
\hline
\end{tabular}




\section{Conclusion}

Considering the influence of defence production, trade and sales, studies should focus on different dimensions of the defence sector to understand the effects on the economy and interaction with other economic variables. This paper presents both well-known and less known data sources on the defence economy and investigates their features.

Two well-known sources, SIPRI and WMEAT, provide military expenditure data sets in different forms. Besides SIPRI trade data sets, COMTRADE, UNIDO and
EUROSTAT present trade figures and many pairs of them have high correlations. Surprisingly, their data sets have been used in few studies. Similarly, output data sets from UNIDO and EUROSTAT have data sets with two revisions each. On the other hand, SIPRI has sales data on the top 100 arms producing firms.

One of the main issue when data sets from different sources are compared is that each one may cover different parts of arms industry. Additionally, some of them rely on classification systems others don't. Therefore, when they are being used the data set it should be prefered depending on the aim. 


\section{Bibliography}

Da Silva, D. L. (2018), Filling Arms Production Data Gaps: South America as a Case in Point, The Economics of Peace and Security Journal 13 (2): 19-25

Fleurant, A and Tian, N. (2018), SIPRI's Arms Producing and Military Services Companies Database, The Economics of Peace and Security Journal, 13 (2): 5-10

Hartley, K. (2018), Arms industry Data: Knowns and Unknowns, Economics of Peace and Security Journal 13 (2): 30-35

http://data.un.org/Data.aspx?d=WDI\&f=Indicator_Code\%3AMS.MIL.XPND.GD.ZS

https://ec.europa.eu/eurostat/web/prodcom/data/ excel-files-nace-rev.2

https://stat.unido.org/

https://www.cia.gov/library/publications/the-worldfactbook/rankorder/2034rank.html

https://www.nato.int/nato_static_fl2014/assets/pdf/ pdf_2017_06/20170629_170629-pr2017-111-en.pdf https://www.state.gov/t/avc/rls/rpt/wmeat/

Kinsella, D. (2000), Arms production in the third tier: An Analysis of Opportunity and Willingness, International Interactions, 26: 3, 253-286

Perlo-Freeman, S. (2018), Arms, Corruption, and the State: Understanding the Role of Arms Trade Corruption in Power Politics, Economics of Peace and Security Journal 13 (2): 36-46

SIPRI.org

Smith, R. and Dunne, J. P. (2018), Issues in the Quantitative Analysis of the SIPRI Arms Industry Database, Economics of Peace and Security Journal 13 (2): 11-18

Wulf, H. (2018), Analysis of SIPRI's Arms Production Data: Some Suggestions for Expansion, The Economics of Peace and Security Journal 13 (2): 26-29

Yesilyurt F., Guloglu B., Yesilyurt M. E. and Sezgin Ş. (2014), The Determinants of Arms Production, Defence and Peace Economics, 25 (2): 205-211 


\section{Online Appendix 1}

\section{Clasiffication system issues}

Classification systems help sort the elements relating to a particular topic in a structured and hierarchical way. This ensures that data collected about a topic are comparable and cover the same concepts. An example is the profession "teacher", which should be grouped in the sector "Education" and not by field of teaching subject. Otherwise a teacher of mathematics might instead be counted in the sector "Scientific activities" (http://ec.europa.eu/eurostat/statistics-explained/ index.php/Beginners:Statistical_concept_-_Classifications accessed on 10 August 2018).

Even though the UN Statistical Division provides a framework classification system, countries or country groups may need additional sub-classifications depending on their own necessities.

\subsection{Classification structure for arms industry}

In order to provide some background to the interpretation of the official data on the arms industry and the arms trade, we will review the two main classification systems that we will introduce data sets considering them.

a) The International Standard Industrial Classification of All Economic Activities (ISIC) consists of a coherent and consistent classification structure of economic activities based on a set of internationally agreed concepts, definitions, principles and classification rules. It has been updated 4 times after first revision by the United Nations. The revisions are Revision 1 published in 1958, Revision 2 published in 1968, Revision 3 published in 1989, Revision 3.1 published by the United Nations in 2002 and Revision 4 published in 2008. While each revisions defined industries more detail, the process of revision precludes the creation of long time series for individual sectors because of changes in the definition of sectors. ISIC Revision 4 contains three parts of the defense industry: ISIC2520 (ISIC revision3 2927); Weapons and Ammunition; ISIC3040; Military Fighting Vehicles and ISIC8422, Defence Activities which covers the operation of the military rather than the manufacture of arms.

b) When adapting ISIC to national circumstances, its categories may be aggregated or disaggregated to better reflect the structure of the national economy of the country. If a particular economic sector is economically of great importance or has developed important specializations that are not separately identified in ISIC, the relevant part of the classification may be further disaggregated (https://osp.stat.gov.lt/ documents/10180/2905525/ISIC_Rev3_1_Introduction.pdf, accessed 20 June 2018). It means that ISIC is an umbrella classification and countries may disaggregate. The classification system for the EU, NACE (Nomenclature statistique des activités économiques dans la Communauté européenne) is an example for this.

Like the ISIC System NACE has been subject to revision and the current classification is NACE Revision 2. In NACE Revision 2, only Weapons and Ammunition NACE2540 (NACE2960 in NACE Revision 1) is specifically classified as an arms industry.

\section{Appendix 2}

\section{ISIC Revision 3}

- Manufacture of tanks and other fighting vehicles,

- Manufacture of heavy weapons (artillery, mobile guns, rocket launchers, torpedo tubes, heavy, machine guns),

- Manufacture of small arms (revolvers, shotguns, light machine guns),

- Manufacture of air or gas guns and pistols,

- Manufacture of war ammunition,

- Manufacture of military ballistic and guided missiles,

- Manufacture of hunting, sporting or protective firearms and ammunition,

- Manufacture of explosive devices such as bombs, mines and torpedoes

- This class excludes:

- Manufacture of percussion caps, detonators or signalling flares, see 2429 ,

- Manufacture of cutlasses, swords, bayonets etc., see 2893,

- Manufacture of armoured vehicles for the transport of banknotes or valuables, see 3410

\section{Online Appendix 3}

\section{ISIC Revision 4}

Weapons and Ammunition ISIC2520 includes

- Manufacture of heavy weapons (artillery, mobile guns, rocket launchers, torpedo

- Tubes, heavy machine guns) 
- Manufacture of small arms (revolvers, shotguns, light machine guns)

- Manufacture of air or gas guns and pistols

- Manufacture of war ammunition

- Manufacture of hunting, sporting or protective firearms and ammunition

- Manufacture of explosive devices such as bombs, mines and torpedoes

On the other hand this class excludes:

- Manufacture of percussion caps, detonators or signalling flares, see 2029

- Manufacture of cutlasses, swords, bayonets etc., see 2593

- Manufacture of armoured vehicles for the transport of banknotes or valuables, see 2910

- Manufacture of space vehicles, see 3030

- Manufacture of tanks and other fighting vehicles, see 3040

Second class for Arms Industry is Military Fighting Vehicles ISIC3040 and includes

- Manufacture of tanks,

- Manufacture of armored amphibious military vehicles,

- Manufacture of other military fighting vehicles,

- This class excludes:

- Manufacture of weapons and ammunitions, see 2520

Third class is Defence Activities ISIC8422 and includes

- Administration, supervision and operation of military defence affairs and land, sea, air and space defence forces such as:

- Combat forces of army, navy and air force,

- Engineering, transport, communications, intelligence, material, personnel and othernon-combat forces and commands,

- Reserve and auxiliary forces of the defence establishment,

- Military logistics (provision of equipment, structures, supplies etc.),
- Health activities for military personnel in the field

- Administration, operation and support of civil defence forces,

- Support for the working out of contingency plans and the carrying out of exercises in which civilian institutions and populations are involved,

- Administration of defence-related R\&D policies and related funds

- This class excludes:

- Research and experimental development activities, see division 72 ,

- Provision of military aid to foreign countries, see 8421 ,

- Activities of military tribunals, see 8423 ,

- Provision of supplies for domestic emergency use in case of peacetime disasters, see 8423 ,

- Educational activities of military schools, colleges and academies, see 8530 ,

- Activities of military hospitals, see 8610

\section{Online Appendix 4}

\section{NACE Revision 1}

2960 Manufacture of weapons and ammunition includes:

- 29601100 Motorized tanks and other armoured fighting vehicles and parts thereof

- 29601200 Military weapons; other than revolvers; pistols and arms of 93.07,

- 29601330 Revolvers and pistols; other than those of 93.03 or 93.04 ,

- 29601350 Muzzle-loading firearms; sporting; hunting or target shooting rifles,

- 29601370 Firearms which operate by firing an explosive charge; n.e.c.,

- 29601390 Other arms (eg spring; air or gas guns and pistols; truncheons),

- 29601410 Cartridges for riveting or similar tools and parts thereof,

- 29601430 Cartridges for shotguns, 
- 29601470 Bombs; grenades; torpedos; mines; missiles and similar munitions; etc,

- 29601530 Parts and accessories of HS 9301 to 9304 (excl. military weapons),

- 29601550 Other; for military weapons falling within HS 9301,

\section{Online Appendix 5}

\section{NACE Revision 2}

2540 Manufacture of Weapons and Ammunition, 2571 Manufacture of cutlery and 2670 Manufacture of optical instruments and photographic equipment incude

- 25401230 Revolvers and pistols (excluding military firearms, machine-pistols, signal flare firearms, blank firers, captive-bolt humane killers, muzzle loaders, spring, air or gas weapons, imitation weapons),
- $\quad 25401250$ Shotguns, rifles, carbines and muzzle-loaders (including punt-guns, combination shotgun-rifles, sporting guns made to resemble walking sticks) (excluding military firearms),

- $\quad 25401270$ Firearms which operate by firing an explosive charge, n.e.c. (excluding military firearms),

- 25401290 Other arms (spring, air or gas guns and pistols, truncheons) (excluding for military purposes),

- 25401300 Cartridges and other ammunition and projectiles and parts thereof, including shot and cartridge wads (excluding for military purposes),

- $\quad 25401400$ Parts and accessories of HS 93.01 to 93.04 (excluding military weapons),

- 25711500 Swords, cutlasses, bayonets, lances and similar arms and parts thereof

- 26702310 Telescopic sights for fitting to arms; periscopes; telescopes 